\title{
Bacteriological and Physicochemical Analyses of Borehole and Well Water Sources in Ijebu-Ode, Southwestern Nigeria
}

\author{
O. O. Bello ${ }_{1}^{*}$, A. $\mathrm{Osho}_{2}$, S.A. Bankole 1 and T. K. Bello 3 \\ ${ }_{1}$ Department of Microbiology, Olabisi Onabanjo University, P.M.B. 2002, Ago-Iwoye, Ogun State, Nigeria. \\ ${ }_{2}$ Department of Biological Sciences, Redeemer's University, Mowe, Ogun State. Nigeria. \\ ${ }_{3}$ Department of Medical Microbiology and Parasitology, Olabisi Onabanjo University Teaching Hospital
}

(OOUTH), Sagamu, Ogun State, Nigeria.

\begin{abstract}
An investigative study was carried out to determine the bacteriological and physicochemical qualities of borehole and well water samples in Ijebu-Ode, Southwestern Nigeria. Ten water samples each of borehole and well water sources were collected within the geographical location. Physicochemical parameters were determined using standard methods. The total bacterial count was determined by pour plate technique and total coliform determined using 3-3-3 regimen. Identifications of isolates were done using standard methods. The colour and turbidity of water samples were within the normal range. Eight genera of bacteria which include Escherichia coli, Klebsiella $s p$, Salmonella $s p$, Shigella $s p$, Enterococcus sp, Proteus sp, Pseudomonas aeruginosa and Staphylococcus aureus were isolated from the water samples. Total bacterial count in borehole and well waters sampled ranged from zero to $2.5 \times 10^{2} \mathrm{cfu} / \mathrm{ml}$ and zero to $8.1 \times 10^{2} \mathrm{cfu} / \mathrm{ml}$, respectively. The total coliform count of the borehole waters analyzed ranged from zero to 16 MPN index of coliform $/ 100 \mathrm{ml}$ while that of well waters ranged from 16 to $1100 \mathrm{MPN}$ index of coliform $100 \mathrm{ml}$ of the water samples. All borehole water samples had zero faecal coliform count while in well water samples, count ranged from zero to $4.1 \times 10^{2} \mathrm{cfu} / \mathrm{ml}$. It was concluded that not all borehole waters are safe for consumption and well waters were of poorer bacteriological qualities indicative of health risk to the inhabitants of the geographical location.
\end{abstract}

Keywords: Borehole, bacteria, coliforms, well, water, quality

\section{Introduction and Literature Review}

Groundwater provides potable water to an estimated 1.5 billion people worldwide daily [1], and has proved the most reliable resource for meeting rural water demand in sub-Saharan Africa [2]. Boreholes equipped with handpumps are a common technology adopted by poor rural communities, and there are currently approximately 250,000 handpumps in Africa [3]. In 1994, it was estimated that $40-50 \%$ of handpumps in subSaharan Africa were not working [4].This is backed up by more recent data from Uganda [5] and South Africa [6], which indicated similar operational failure rates. An evaluation in Mali in 1997 found $90 \%$ of pumps inoperable just one year after installation [7]. The primary reason for these high failure rates, and hence low sustainability, is insufficient attention to operation and maintenance of the pump [8]. This borehole itself, however, is sometimes the source of the problem. Microbial contamination of collected and stored household water is caused not only by the collection and use of faecally contaminated water that was not safe, to begin with, but also by contamination of initially microbiologically safe water after its collection and storage. Factors contributing to this problem are unsanitary and inadequately protected (open, uncovered or poorly covered) water collection and storage containers, the use of unsanitary methods to dispense water from household storage vessels, including faecally contaminated hands and dippers, lack of protection against contamination introduced by vectors (flies, cockroaches, rodents, etc.) and inadequate cleaning of vessels to prevent biofilm formation and accumulation of sediments and pathogens. Improving and protecting the microbial quality and reducing the infectious disease risks to consumers of collected water stored in households requires alternative or interim strategies and approaches that can be implemented effectively, quickly and affordably [8]. Technically feasible, effective, socio-culturally acceptable and affordable methods for treatment and storage of household water to improve microbial quality and reduce waterborne disease risks are now available. Waiting for the provision of piped, microbiologically safe community water systems to the many people lacking such services is an inappropriate response to the basic need for safer drinking water that can be met on, at least, a provisional basis by available technologies. Effective measures are needed immediately to provide at risk populations with safer water at the household level until the long-term goal of providing safe, piped, community water supplies can be achieved $[7,8,9]$. There is now conclusive evidence that simple, acceptable, low-cost interventions at the household and community level are capable of dramatically improving the microbial quality of household stored water and reducing the risks of diarrheal disease and death in populations of all ages in the developed and developing world. A variety of physical and chemical treatment methods to improve the microbial quality of water are available and many have been tested and implemented to varying extents in a variety of settings and 
for a diverse range of populations. Many different water collection and storage systems and strategies have been developed, described and evaluated on the basis of various criteria for household and community use. Some of them have been tested under controlled conditions in the laboratory and implemented in field to evaluate their ability to produce drinking water of acceptable microbiological quality and to maintain this quality during storage and use $[8,9]$. Some of them also have been evaluated in the field for their ability to reduce diarrheal and other waterborne diseases among users. Because of the importance of education, socio-cultural acceptance, changing people's beliefs and behaviors, achieving sustainability and affordability in the provision of safe water, some of the most promising household water treatment and storage systems and their implementation strategies include or are accompanied by efforts to address these considerations. It is necessary to critically review the various candidate technologies and systems for providing microbiologically improved household water and to identify the most promising ones based on their technical characteristics and performance criteria. These characteristics and performance criteria are: effectiveness in improving and maintaining microbial water quality, reducing waterborne infectious disease, technical difficulty or simplicity, accessibility, cost, socio-cultural acceptability, sustainability and potential for dissemination [9]. However, it is now apparent that improving household water collection, treatment and storage is one option for achieving a beneficial health effect by reducing diarrheal and other infectious diseases $[10,11,12,13,14]$. In many developing countries, availability of water has become a critical and urgent problem and it is a matter of great concern to families and communities depending on non-public water supply system [15]. Increase in human population has exerted an enormous pressure on the provision of safe drinking water especially in developing countries [16]. Unsafe water is a global public health threat, placing persons at risk for a host of diarrheal and other diseases as well as chemical intoxication [17]. Unsanitary water particularly has devastating effects on young children in the developing world. Each year, more than 2 million persons, mostly children less than 5 years of age, die of diarrheal disease $[18,19]$. For children in this age group, diarrheal disease accounted for 17\% of all death from 2000 to 2003 ranking third among causes of death, after neonatal causes and acute respiratory infections [20]. Nearly $90 \%$ of diarrheal-related deaths have been attributed to unsafe or inadequate water supplies and sanitation conditions affecting a large part of the world's population [17,21]. An estimated 1.1 billion persons (one sixth of the world's population) lack access to clean water and 2.6 billion to adequate sanitation [17,20]. The principal objectives of municipal water are the production and the distribution of safe water that is fit for human consumption [15,22]. Recently in Nigeria, drinking water is commercially available in easy-to-open $50-60 \mathrm{ml}$ polyethylene sacks known as sachet water [16]. Conformation with microbiological standard is of special interest because of the capacity of water to spread diseases within a large population. Although the standards vary from place to place, the objective anywhere is to reduce the possibility of spreading water-borne disease in addition to being pleasant to drink, which implies that it must be wholesome and palatable in all respects $[9,15$, 23]. A collaborative, interdisciplinary effort to ensure global access to safe water, basic sanitation, and improved hygiene is the foundation for ending cycle of poverty and diseases [17].In line with objective of MDG (Millennium Development Goals) adopted by the Federal Republic of Nigeria is the provision of safe potable water and because of the limitation of funds for this provision and others, Ogun State of Nigeria adopted the provision of safe borehole water to augment that of treated water in all parts of the state including Ijebu-Ode metropolis. High level of chlorine in treated public water supply could react with organic matters to form organochlorine compounds which has been found to be carcinogenic when consumed over a long period of time. Hence, a high percentage of people are turning to the use of borehole water for domestic chores and drinking even though Sule et al. [24] in a recent research found out that stressed bacterial cells reactivate faster in dechlorinated water than in chlorinated water. Household water treatment and storage systems are one of many water, sanitation and hygiene options that deserve due consideration in the identification, prioritization and implementation of water, sanitation and hygiene measures for use at household, community and regional levels. It is assumed that treated community water supplies in developed countries generally are of high microbiological quality and therefore safe with respect to waterborne microbial disease risks. However, significantly increased risks of waterborne gastrointestinal illness have been attributed to a centralized community water supply system in a large city of a developed Country (Laval, Quebec, Canada) where water was extensively treated by modern methods and met all microbial quality requirements [25]. Additionally, the infectious disease risks from faecally contaminated and microbially unsafe water in developed countries is considered even greater in the water supplies of smaller communities than the larger ones [26]. Small community water supplies are at greater risk than larger ones because they often lack the technical expertise and financial resources to adequately protect source waters, provide sufficient and technically reliable treatment and maintain the integrity of their distribution systems. For example, most waterborne outbreaks in the United States of America are due to systems with no or inadequate treatment, vulnerable watersheds and aquifers, distribution system deficiencies serving smaller communities. Therefore, it should come as no surprise that in communities throughout the world, improving household water quality by point-of-use treatment reduces risks of diarrheal disease and significantly improves microbial quality. The objectives of this study are to determine the 
physicochemical parameters of the borehole and well waters; the bacteriological quality of water produced by these water sources; and the safety and potability of the waters

\subsection{Study Area}

\section{Materials and Methods}

Ijebu-Ode, town, Ogun state, Southwestern Nigeria is situated along the highway between Shagamu and Benin City. Ijebu-Ode was by the 16th century established as the chief town of the Ijebu people (a subdivision of the Yoruba). As the seat of the Awujale, the Ijebu political and spiritual ruler, it served as the capital of the Ijebu kingdom, which for several centuries dominated the trade between the ports of the Lagos Lagoon (including Lagos, 44 miles [70 km] west-southwest) and the Yoruba hinterland (especially Ibadan, 38 miles $[60 \mathrm{~km}]$ north). Modern Ijebu-Ode is a major collecting station for kola nuts, which are purchased for trucking to the northern states. Ijebu-Ode also serves as a collecting point for cocoa and palm oil and kernels, which are exported from Lagos. The town's industry includes printing and publishing firm. Its artisans are known for their handiwork in iron. Local trade is primarily in yams, cassava (manioc), corn (maize), palm produce, and oranges; and rubber and timber have become important commercial products of the area.

\subsection{Collection of Water Samples \\ 2.2.1 Borehole water}

Ten water samples were collected from ten boreholes within Ijebu-Ode metropolis using sterile sampling bottles. The samples were from Oke-Aje, Degun, Obalende, Stadium road, Abeokuta road, Ita-Ale, Lagos garage road, Ibadan garage road, Imowo and Ejirin, all within Ijebu-Ode Metropolis, Ogun State, Nigeria using standard methods as described by APHA [28].

\subsubsection{Well water}

Water samples were collected from ten different wells in the same geographical location with the use of sterile sample bottles. A strong thread was attached to the neck of each sterile bottle and gently released into the well; the opened bottle was allowed to sink below the water and was pulled up after observing there were no more bubbles from the bottle. The bottle was gently raised out of the well without allowing bottle to touch the sides of the wells. The caps were carefully replaced and the sample was transported in ice bath to the laboratory for immediate analysis.

\subsection{Physicochemical Parameters}

The $\mathrm{pH}$ readings of the water samples were taken using $\mathrm{pH}$ meter Wag WT 3020. The $\mathrm{pH}$ meter was standardized with buffer 4, 7 and 9 before being used [24]. Temperature of each sample was determined using mercury-bulb thermometer and this was recorded at the point of collection of sample before being transported to the laboratory. Both colour and turbidity of each of the samples were determined using WagWT3020 turbidimeter.

\subsection{Bacteriological Quality Determination \\ 2.4.1 Total Bacterial Count}

The total bacterial count was determined by pour plate technique using standard methods [27]. Nutrient agar medium was used for the enumeration of bacteria in the samples. Mannitol salt agar was used for the isolation of Staphylococcus aureus while Salmonella sp was isolated on Salmonella-Shigella agar.

\subsubsection{Total Coliform Count}

This was determined by MPN index method using 3-3-3 regimen. MacConkey broth was used and positive result was indicated by acid and gas production on incubation at $37^{\circ} \mathrm{C}$ for 48 hours [28].

\subsubsection{Faecal Coliform Count}

Faecal coliform count was determined using Eosin Methylene Blue medium employing the pour plate technique. On Eosin Methylene Blue (EMB) agar, E. coli strains appeared as greenish metallic sheen colonies and this was further confirmed by the ability of the organism to ferment lactose at $44.5^{\circ} \mathrm{C}$ while Aerobacter aerogenes appeared as large pinkish mucoid colonies [29].

\subsubsection{Identification of Isolates}

Identifications of all isolates were done using standard methods as described by APHA [27], Fawole and Oso [28] and Burnett and Beuchat [29]. 


\section{Results and Discussion}

The $\mathrm{pH}$ of the borehole waters sampled ranged from 6.4 to 7.4 while that of well waters ranged from 6.3 to 7.5. Both borehole and well waters analyzed maintained normal temperature range of $22-28^{0} \mathrm{C}$ and $21-$ $27^{\circ} \mathrm{C}$, respectively. The colour and turbidity of borehole waters sampled on Wag WT 3020 turbidimeter had a range of $2-6$ True Colour Unit (TCU) and 2-5 Nephelometric unit (NTU) respectively (Table 1) while that of well water had range of 3-6 TCU and 3-6 NTU which are all normal ranges for waters purported to be safe and wholesome for consumption. This $\mathrm{pH}$ range is close to neutrality and would allow the growth of most bacterial species. Eniola et al. [30] obtained similar $\mathrm{pH}$ ranges of $6.54-7.80$ and 6.54 to 7.90 for borehole water samples stored indoor and outdoor in containers of different colours. Colour is an important physical quality of water which affects its acceptability by consumers. Ninety percent of the borehole water samples were within the acceptable limit of $5 \mathrm{TCU}[31,32]$. The mineral composition of the site could affect the colour of the water especially if iron compounds are present. The turbidity of the borehole water samples ranged from 2-5 NTU. This is also in conformity with the acceptable values [31,32]. Turbidity results from the presence in the borehole water samples of particulate matters such as clay, silt, finely divided organic matter etc. These colloidal materials provide adsorption sites for chemicals that may be harmful to health or cause undesirable tastes or odours [33]. The temperature of any water body affects the rate of proliferation of microorganisms [34]. The temperature range of $22-28^{\circ} \mathrm{C}$ (in the case of borehole water samples) and $21-27^{\circ} \mathrm{C}$ (for well water samples) could be said to be suitable for the growth of heterotrophic bacterial species when present in the sample (Table 1).

Table 1: Physicochemical parameters of borehole and well water samples in Ijebu-Ode, Southwestern Nigeria.

\begin{tabular}{|c|c|c|c|c|c|}
\hline Sample & & $\mathrm{pH}$ & Temperature $\left({ }^{0} \mathrm{C}\right)$ & Colour (TCU) & Turbidity (NTU) \\
\hline $\mathrm{A}$ & & 6.5 & 25 & 3 & 5 \\
\hline $\mathrm{B}$ & & 6.4 & 27 & 5 & 5 \\
\hline $\mathrm{C}$ & $\bar{s}$ & 6.8 & 22 & 6 & 3 \\
\hline $\mathrm{D}$ & $\sum_{\pi}^{\frac{\pi}{2}}$ & 7.1 & 26 & 4 & 2 \\
\hline $\mathrm{E}$ & 3 & 7.3 & 25 & 3 & 4 \\
\hline $\mathrm{F}$ & 8 & 7.4 & 24 & 5 & 5 \\
\hline G & D & 6.7 & 28 & 4 & 3 \\
\hline $\mathrm{H}$ & ஜ & 7.3 & 27 & 5 & 4 \\
\hline I & & 7.0 & 23 & 2 & 5 \\
\hline $\mathrm{J}$ & & 7.2 & 24 & 5 & 5 \\
\hline $\mathrm{K}$ & & 7.0 & 23 & 4 & 5 \\
\hline $\mathrm{L}$ & & 6.8 & 25 & 4 & 3 \\
\hline M & $\overline{0}$ & 6.7 & 24 & 5 & 5 \\
\hline $\mathrm{N}$ & है & 6.0 & 27 & 3 & 4 \\
\hline $\mathrm{O}$ & 3 & 6.3 & 22 & 4 & 3 \\
\hline $\mathrm{P}$ & $\overline{0}$ & 6.5 & 24 & 5 & 4 \\
\hline Q & 3 & 7.2 & 21 & 4 & 3 \\
\hline $\mathrm{R}$ & & 6.9 & 24 & 6 & 5 \\
\hline $\mathrm{S}$ & & 7.1 & 22 & 4 & 6 \\
\hline $\mathrm{T}$ & & 7.5 & 25 & 5 & 4 \\
\hline
\end{tabular}

Eight genera of bacteria which include Escherichia coli, Klebsiella spp, Salmonella spp, Shigella spp, Enterococcus spp, Proteus spp, Pseudomonas aeruginosa and Staphylococcus aureus were isolated from both borehole and well waters as shown in Table 2. On Eosin Methylene Blue (EMB) agar, E. coli strains appeared as greenish metallic sheen colonies while Aerobacter aerogenes appeared as large pinkish mucoid colonies. All biochemical characteristics of isolates were presented in Table 2

Table 2: Biochemical characterization of isolated microorganisms from borehole and well water samples in Ijebu-Ode, Southwestern Nigeria

\begin{tabular}{|c|c|c|c|c|c|c|c|c|c|c|c|c|c|c|c|c|c|c|}
\hline 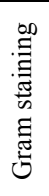 & 总 & 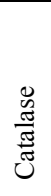 & 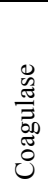 & $\frac{c}{c}$ & 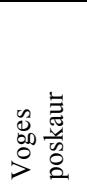 & 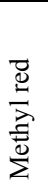 & 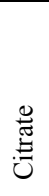 & 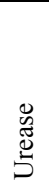 & 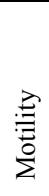 & $\stackrel{\Xi}{\bar{\Xi}}$ & $\stackrel{\text { 工 }}{\text { 工 }}$ & $\stackrel{\mathscr{U}}{0}$ & 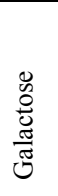 & $\begin{array}{c}0 \\
0 \\
0 \\
0 \\
0\end{array}$ & 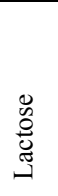 & 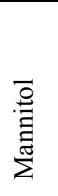 & $\begin{array}{c}0 \\
\infty \\
0 \\
\stackrel{0}{0} \\
\tilde{\infty}\end{array}$ & $\begin{array}{l}\text { Suspected } \\
\text { Microorganism }\end{array}$ \\
\hline+ & $\begin{array}{l}\text { Coc } \\
\mathrm{ci}\end{array}$ & + & + & - & - & - & - & - & - & - & - & - & $\mathrm{AG}$ & $\mathrm{AG}$ & $\mathrm{AG}$ & $\mathrm{AG}$ & $\mathrm{AG}$ & Staphlococcus aureus \\
\hline+ & $\begin{array}{l}\mathrm{Coc} \\
\mathrm{ci}\end{array}$ & - & - & - & - & - & - & - & - & - & - & - & AG & AG & AG & $\mathrm{AG}$ & AG & Enterococcus spp \\
\hline- & $\begin{array}{l}\text { Rod } \\
\text { Rod } \\
\text { Rod } \\
\end{array}$ & $\begin{array}{l}- \\
-\end{array}$ & $\begin{array}{l}- \\
-\end{array}$ & $\begin{array}{l}+ \\
-\end{array}$ & - & + & $\overline{+}$ & $\overline{+}$ & $\begin{array}{l}+ \\
-\end{array}$ & $\begin{array}{l}- \\
\overline{+} \\
\end{array}$ & $\begin{array}{l}- \\
\overline{+} \\
\end{array}$ & $\begin{array}{l}- \\
+ \\
\end{array}$ & $\begin{array}{l}\mathrm{AG} \\
\mathrm{AG} \\
\mathrm{AG}\end{array}$ & $\begin{array}{l}\text { AG } \\
\text { AG } \\
\mathrm{AG}\end{array}$ & $\begin{array}{l}\mathrm{AG} \\
\mathrm{AG} \\
\mathrm{AG}\end{array}$ & $\begin{array}{l}\mathrm{AG} \\
\mathrm{AG} \\
\mathrm{AG}\end{array}$ & $\begin{array}{l}\text { A } \\
\text { AG } \\
\text { NAG }\end{array}$ & $\begin{array}{l}\text { Escherichia coli } \\
\text { Klebsiella } \text { spp } \\
\text { Salmomella spp }\end{array}$ \\
\hline
\end{tabular}


Bacteriological and Physicochemical Analyses of Borehole and Well Water Sources in Ijebu-Ode,

\begin{tabular}{|c|c|c|c|c|c|c|c|c|c|c|c|c|c|c|c|c|c|c|}
\hline- & Rod & + & - & - & + & - & + & - & - & + & - & - & $\mathrm{AG}$ & $\mathrm{AG}$ & $\mathrm{AG}$ & $\mathrm{AG}$ & $\mathrm{AG}$ & Aerobacter aerogenes \\
\hline- & $\begin{array}{l}\text { Rod } \\
\text { Rod }\end{array}$ & - & - & - & - & - & $\begin{array}{l}- \\
-\end{array}$ & $\begin{array}{l}+ \\
-\end{array}$ & - & $\begin{array}{l}- \\
-\end{array}$ & $\begin{array}{l}- \\
-\end{array}$ & $\begin{array}{l}- \\
-\end{array}$ & $\begin{array}{l}\mathrm{AG} \\
\mathrm{AG}\end{array}$ & $\begin{array}{l}\text { AG } \\
\text { NA } \\
\text { G }\end{array}$ & $\begin{array}{l}\text { AG } \\
\text { NA } \\
\text { G }\end{array}$ & $\begin{array}{l}\text { AG } \\
\text { NA } \\
\text { G }\end{array}$ & $\begin{array}{l}\mathrm{AG} \\
\mathrm{AG}\end{array}$ & $\begin{array}{l}\text { Proteus spp } \\
\text { Pseudomonans } \\
\text { aeruginosa }\end{array}$ \\
\hline
\end{tabular}

KEY

+: positive; __ _ Negative;

AG: Acid and gas production; NAG: No acid and gas production

The total bacterial count in borehole and well waters sampled ranged from zero to $2.5 \mathrm{x} 10^{2} \mathrm{cfu} / \mathrm{ml}$ and zero to $8.1 \times 10^{2} \mathrm{cfu} / \mathrm{ml}$, respectively with about eighty percent of the samples having count within the limit of 100 $\mathrm{cfu} / \mathrm{ml}$ allowed for potable water [32]. Similarly, the total coliform count of the borehole waters analyzed ranged from zero to $16 \mathrm{MPN}$ index of coliform/100 ml while that of well waters ranged from 16 to $1100 \mathrm{MPN}$ index of coliform $/ 100 \mathrm{ml}$ of the water samples. All the borehole water samples had zero count of faecal coliform while in well water samples, the faecal coliform count ranged from zero to $4.1 \times 10^{2} \mathrm{cfu} / \mathrm{ml}$ (Table 3). Erah et al . [35] in a study conducted on the quality of ground water in Benin City, Nigeria found unacceptable levels of aerobic bacteria and fungi present in borehole water of Teboga District of Benin City. In another similar work, Eniola et al. [30] obtained a range of $5.0 \times 10^{2}$ to $7.0 \times 10^{2} \mathrm{cfu} / \mathrm{ml}$ for stored borehole water samples. All the borehole water samples were devoid of faecal coliform, they were however not free of total coliforms which were probably from the environmental sources and were nonfaecal in origin. WHO [31] specified that potable drinking water should be devoid of total coliform in any given sample. The borehole water (sample B) with the highest bacterial count also had the highest total coliform count (Table 3). It is note-worthy to mention that 50\% of the borehole water samples had zero total coliform counts. Results of total coliforms obtained in this study is dissimilar to that of Rogbesan et al. [36] who in their study, reported the presence of total coliform outside the range allowed by WHO in over sixty percent of their samples.

Table 3: Bacteriological counts of borehole and well water samples in Ijebu-Ode, Southwestern Nigeria

\begin{tabular}{|c|c|c|c|c|c|}
\hline Sample & & $\begin{array}{l}\text { Total Bacterial Count }\left(\times 10^{2}\right. \\
\mathrm{cfu} / \mathrm{ml} \text { ) }\end{array}$ & $\begin{array}{l}\text { Total Coliform } \\
\text { (MPN/100ml) }\end{array}$ & Count & $\begin{array}{l}\text { Faecal Coliform Count }(\mathrm{x} \\
\left.10^{2} \mathrm{cfu} / \mathrm{ml}\right)\end{array}$ \\
\hline $\bar{A}$ & & 0 & 0 & & 0 \\
\hline B & & 2.5 & 16 & & 0 \\
\hline $\mathrm{C}$ & & 1.0 & 0 & & 0 \\
\hline $\mathrm{D}$ & $\bar{\Xi}$ & 0.41 & 6 & & 0 \\
\hline E & 3 & 0 & 0 & & 0 \\
\hline $\mathrm{F}$ & $\cong$ & 1.25 & 13 & & 0 \\
\hline G & $\frac{8}{0}$ & 0.61 & 9 & & 0 \\
\hline $\mathrm{H}$ & 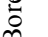 & 0 & 0 & & 0 \\
\hline I & & 0 & 0 & & 0 \\
\hline $\mathrm{J}$ & & 0 & 0 & & 0 \\
\hline K & & 3.8 & 36 & & 1.0 \\
\hline $\mathrm{L}$ & & 4.5 & 210 & & 2.2 \\
\hline M & $\ddot{\jmath}$ & 7.6 & 1100 & & 3.0 \\
\hline $\mathrm{N}$ & 苞 & 0 & 16 & & 0 \\
\hline $\mathrm{O}$ & 3 & 8.1 & 1100 & & 4.1 \\
\hline P & $\overline{0}$ & 5.2 & 240 & & 2.0 \\
\hline Q & & 3.8 & 53 & & 0 \\
\hline $\mathrm{R}$ & & 7.8 & 1100 & & 3.0 \\
\hline$S$ & & 8.0 & 1100 & & 4.0 \\
\hline $\mathrm{T}$ & & 3.6 & 43 & & 1.0 \\
\hline
\end{tabular}

E. coli was absent in all borehole water samples but was found present in three of ten wall waters (M, R and S) analyzed for bacteriological quality. Four of ten borehole water samples (B, D, F and G) analyzed was found to contain three or more of the bacterial contaminants while the remaining six (A, C, E, H, I and J) were devoid of these organisms. It was, however, observable that Proteus sp. and A. aerogenes were most predominant in the borehole waters analyzed as they were isolated from three of the ten different ancestral samples (Table 4). The ten well waters sampled were found to contain, at least, one of E. coli, Proteus sp, S. aureus, Klebsiella sp., Micrococcus sp. and A. aerogenes. The most predominant organisms being S. aureus and A. aerogenes as they both occurred in six of ten well waters under study (Table 4). The presence of Klebsiella sp., Micrococcus sp. and Aerobacter aerogenes in some of the borehole and well water samples is unacceptable from the public health point of view. These organisms could be pathogenic. Therefore, there is need for caution when using these contaminated water sources for any purposes. Eniola et al. [30] obtained some members of coliform in stored borehole water samples. 
Bacteriological and Physicochemical Analyses of Borehole and Well Water Sources in Ijebu-Ode,

Table 4: Occurrence of bacterial species in borehole and well water samples in Ijebu-Ode, Southwestern Nigeria

\begin{tabular}{|c|c|c|c|c|c|c|c|}
\hline Sample & & Escherichia coli & Proteus sp & Staphylococcus aureus & Klebsiella $\mathrm{sp}$ & Micrococcus sp & $\begin{array}{l}\text { Aerobacter } \\
\text { aerogenes }\end{array}$ \\
\hline A & & - & - & - & - & - & - \\
\hline B & & - & + & + & - & - & + \\
\hline C & $\ddot{\Phi}$ & - & - & - & - & - & - \\
\hline D & $\sum_{\pi}^{\frac{\pi}{n}}$ & - & + & - & + & - & + \\
\hline E & 0 & - & - & - & - & - & - \\
\hline $\mathrm{F}$ & $\overline{8}$ & - & + & - & + & + & - \\
\hline G & D̆ & - & - & + & - & + & + \\
\hline $\mathrm{H}$ & $\infty$ & - & - & - & - & - & - \\
\hline I & & - & - & - & - & - & - \\
\hline $\mathrm{J}$ & & - & - & - & - & - & - \\
\hline K & & - & + & - & + & - & - \\
\hline $\mathrm{L}$ & & - & - & - & + & - & - \\
\hline M & & + & + & + & - & + & + \\
\hline $\mathrm{N}$ & $\frac{\bar{\Xi}}{\sigma}$ & - & - & - & + & - & + \\
\hline $\mathrm{O}$ & 3 & - & + & - & - & - & + \\
\hline $\mathrm{P}$ & $\overline{0}$ & - & - & + & - & - & - \\
\hline Q & 3 & - & - & + & - & + & - \\
\hline $\mathrm{R}$ & & + & - & + & + & + & + \\
\hline S & & + & - & + & + & - & + \\
\hline $\mathrm{T}$ & & - & - & + & - & - & + \\
\hline
\end{tabular}

Sanitary survey of the borehole sites revealed the proximity of some of the boreholes to solid waste dump site and animal droppings being littered around them. A total of ten borehole and ten well waters were sampled from sources in Ijebu-Ode, Ogun State, Nigeria. The depth of the well ranged from approximately 17 to $25 \mathrm{ft}$ with three of the wells maintaining same depth of approximately $24 \mathrm{ft}$ deep. Five of the well openings were unraised but however, not at ground level while the remaining five were pronouncedly raised above ground level (Table 5). All ten wells were covered and concrete internal rings were present in six. All well waters sampled for analyses were being used for drinking, cooking and washing purposes by the households and some other inhabitants of the community.

Table 5: Sanitary surveillance of borehole and well sampling points in Ijebu-Ode, Southwestern Nigeria

\begin{tabular}{|c|c|c|c|c|c|c|c|c|}
\hline Sample & & $\begin{array}{l}\text { Solid } \\
\text { Dump }\end{array}$ & Waste & $\begin{array}{l}\text { Animal and/or } \\
\text { Fowls Droppings }\end{array}$ & Depth (ft) & Well Opening & Well Cover & $\begin{array}{l}\text { Concrete internal } \\
\text { ring }\end{array}$ \\
\hline $\mathrm{A}$ & & - & & - & ND & NA & $\overline{\mathrm{NA}}$ & NA \\
\hline B & & - & & + & ND & NA & NA & NA \\
\hline $\mathrm{C}$ & $\overline{0}$ & - & & - & ND & NA & NA & NA \\
\hline D & 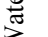 & + & & + & ND & NA & NA & NA \\
\hline $\mathrm{E}$ & 30 & - & & - & ND & NA & NA & NA \\
\hline $\mathrm{F}$ & $\frac{0}{0}$ & + & & + & ND & NA & NA & NA \\
\hline G & ల్లై & + & & + & ND & NA & NA & NA \\
\hline $\mathrm{H}$ & ๑ీ & - & & - & ND & NA & NA & NA \\
\hline I & & - & & - & ND & NA & NA & NA \\
\hline $\mathrm{J}$ & & - & & - & ND & NA & NA & NA \\
\hline $\mathrm{K}$ & & - & & - & 17 & Raised & Covered & Present \\
\hline $\mathrm{L}$ & $\overrightarrow{0}$ & - & & - & 24 & Unraised & Covered & Present \\
\hline M & $\frac{0}{\pi}$ & - & & + & 18 & Raised & Covered & Absent \\
\hline $\mathrm{N}$ & 3 & - & & - & 24 & Raised & Covered & Present \\
\hline $\mathrm{O}$ & $\overline{0}$ & + & & + & 24 & Unraised & Covered & Absent \\
\hline $\mathrm{P}$ & 3 & - & & - & 20 & Raised & Covered & Present \\
\hline Q & & - & & - & 22 & Raised & Covered & Present \\
\hline $\mathrm{R}$ & & + & & + & 18 & Unraised & Covered & Absent \\
\hline $\mathrm{S}$ & & - & & - & 25 & Unraised & Covered & Absent \\
\hline $\mathrm{T}$ & & - & & - & 22 & Unraised & Covered & Present \\
\hline
\end{tabular}

Keys: ND - Not determined; NA - Not Applicable; - Absent and + Present

\section{Conclusion}

This investigation suggests that not all borehole waters are safe for consumption and well waters were of poorer bacteriological qualities indicative of health risk to the inhabitants of the geographical location. The sites of boreholes and wells are very important as clean and hygienic environment promote safety of water. The geologist drilling boreholes have to be educated on the importance of ensuring that dump sites are not used for drilling of boreholes. Moreover, the populace needs to be educated on the importance of maintaining clean and 
hygienic environment around the borehole and well waters to ensure the safety of water from such sources. There is need to carry out a comprehensive epidemiological study to determine the number of people suffering from diseases or illnesses related to the microbial water quality problems identified in the area of study. This will provide information on the actual health problems on ground as well as contribute to the use of untreated groundwater in schools. This will lead to recommendation of realistic remediation methods for each specific health problem. Information obtained would be valuable in the design and implementation of intervention strategies if required. Hence, this will enable the provision of data available to indicate that groundwater in the study areas does not meet the national guidelines of water for human consumption unless treated before use. Interventions such as the implementation of point of use water treatment could be advocated.

\section{References}

[1]. DFID. Addressing the Water Crisis: Healthier and more productive lives for poor people, Strategies for achieving the international development targets. Department for International Development: UK., 2001,2 - 3 .

[2]. A.M. MacDonald and J. A Davies. Brief Review of Groundwater for Rural Water Supply in Sub-Saharan Africa. British Geological Survey Technical Report WC/00/33, Nottingham, UK. 2000, 9-10.

[3]. HTN. Focus on Africa, a critical need. Network for Cost-Effective Technologies in Water Supply and Sanitation, St. Gallien, Switzerland, 2003, 15-19.

[4]. Diwi Consult and Bureau d'Ingénierie pour le Développement Rural (BIDR). Etudes d' Réhabilitation des Points d' Eau Existants. 1994, 11-13

[5]. DWD. Overview of the Water Sector, Reform, SWAP and Financial Issues. Directorate of Water Development, Ministry of Water, Lands and Environment, The Republic of Uganda. 1(1), 2002, 12-15.

[6]. D. Hazelton. The development of community water supply systems using deep and shallow well handpumps. WRC Report No, TT132/00, Water Research Centre, South Africa, 2000, 22-24.

[7]. World Bank. Mali Rural Water Supply Project. Performance Audit Report No. 16511, World Bank, Washington DC. 1997, 10-12.

[8]. Harvey, P.A. and Reed, R.A. Rural Water Supply in Africa: Building blocks for handpump sustainability. WEDC, Loughborough University, UK., 2004, 46- 49.

[9]. J.C. Semenza, L. Roberts, A. Henderson, J. Bogan and C.H. Rubin. "Water Distribution System and Diarrheal Disease Transmission: A Case Study in Uzbekistan." American Journal of Tropical Medicine and Hygiene 59(6),1998, 941-946.

[10]. M. Wegelin and B. Sommer. "Solar water disinfection (SODIS) - Destined for worldwide use?" Waterlines 16(3), 2002, 30-32.

[11]. K.G. McGuigan, T.M. Joyce and R.M. Conroy. "Solar disinfection: Use of sunlight to decontaminate drinking water in developing countries." Journal of Medical Microbiology 48(9), 2006,785-787.

[12]. K.G. McGuigan, T.M. Joyce, R.M. Conroy, J.B. Gillespie and M. Elmore-Meegan. Solar disinfection of drinking water contained transparent plastic bottles: Characterizing the bacterial inactivation process. Journal of Applied Microbiology. 84(6): 2008, 11381148 .

[13]. B. Sommer, A. Marino, Y. Solarte, M.L. Salas, C. Dierolf, C. Valiente, D. Mora, R. Rechsteiner, P. Setter, W. Wirojanagud, H. Ajarmeh, A. Al-Hassan, and M. Wegelin. "SODIS: An emerging water treatment process." Aqua (Oxford). 46 (3),2007, 127-137.

[14]. T. Handzel. The Effect of Improved Drinking Water Quality on the Risk of Diarrheal Disease in an Urban Slum of Dhaka, Bangladesh: A Home Chlorination Intervention Trial. Doctoral Dissertation. Department of Environmental Sciences and Engineering. University of North Carolina, Chapel Hill, UNC: 2008, 110-104.

[15]. I.O. Okonko, A.A. Ogunjobi, A.D. Adejoye, T.A. Ogunnusi and M.C. Olasogba. Comparative studies and microbial risk assessment of different water samples used for processing frozen sea foods in Ijora-olopa,Lagos State,Nigeria. African Journal of Biotechnology, 7 (16), 2008, 2902-2907.

[16]. C.N. Umeh, O.I. Okorie and G.A. Emesiani. Towards the provision of safe drinking water: The bacteriological quality and safety of sachet water in Awka, Anambra State. In: the Book of Abstract of the 29th Annual Conference and General Meeting on Microbes As Agents of Sustainable Development, organized by Nigerian Society for Microbiology (NSM), University of Agriculture, Abeokuta, 2005, 14-17.

[17]. J.M. Hughes and J.P. Koplan. Saving Lives through Global Safe Water. Journal of Emerging Infectious Diseases, 11(10),2005,16361637.

[18]. M. Kosek, C. Bern and R.L. Guerrant. The global burden of diarrhoeal disease, as estimated from studies published between 1992 and 2000. Bulletin of World Health Organization, 81, 2003,197-204.

[19]. U. Parashar, J.S. Bresee and R.I. Glass. The global burden of diarrhoeal disease in children. Bulletin World Health Organization, $81,2003,236$

[20]. WHO. Financial management of water supply and sanitation. World Health Organization. Geneva, 2005.

[21]. WHO. Water, sanitation and hygiene links to health, $2004 \mathrm{http} / / \mathrm{www}$.who.int/water_sanitation $\mathrm{h}$ ealth/publications/facts2004/en/print.

[22]. A. Lamikanra. Essential Microbiology for students and practitioner of Pharmacy, Medicine and Microbiology (2nd edn. Amkra books, Lagos, 1999).

[23]. M.O. Edema, A.M. Omemu and O.M. Fapetu (2001). Microbiology and Physiochemical Analysis of different sources of drinking water in Abeokuta. Nigeria. Nigerian Journal of Microbiology, 15(1): 57-61.

[24]. I.O. Sule, G.P.O. Oyeyiola. and T.O. Agbabiaka. Comparative Bacteriological Analysis of Chlorinated and Dechlorinated Pipeborne Water. International Journal of Biological Science, 1 (1), 2009, 93-98.

[25]. P. Payment and R. Armon. "Virus Removal by Drinking Water Treatment Processes." Critical Review in Environmental Control 19(1), 2007, 15-31.

[26]. R.E. Quick, L.V. Venczel, E. D. Mintz, 1. Soleto, J. Aparicio, M. Gironaz, et al. "Diarrhoea Prevention in Bolivia through Point-ofUse Water Treatment and Safe Storage: a Promising New Strategy." Epidemiology and Infection 122 (4), 1999, 83-90.

[27]. APHA (American Public Health Association). Standard Methods for the Examination of Water and Wastewater. 14thedition. American Public Health Association, Washington D.C. 1985.

[28]. M.O. Fawole and B.A. Oso. Laboratory Manual of Microbiology. Ibadan, Nigeria (Spectrum Books. 2001) 15-45.

[29]. S.L. Burnett and L.R. Beuchat. Human Pathogens associated with raw produce and unpasteurized juices, and difficulties in contamination. Journal of Industrial Microbiology and Biotechnology 27(6) 2001, 104-110. 
[30]. K.I.T. Eniola, D.Y. Obafemi, S.F. Awe, I.I. Yusuf and O.A. Falaiye. Effects of Containers and Storage conditions on Bacteriological Quality of Borehole Water. Nigerian Journal of Microbiology, 21(3), 2007, 1578 - 1585.

[31]. WHO (World Health Organization). WHO International Standards for Drinking Water, 1985, 10-15.

[32]. NSDWQ (Nigerian Standard for Drinking Water Quality). National Standard for Drinking Water Quality, 2007, 1-22.

[33]. I.M. Adekunle, M.T. Adekunle, A.M. Gbadebo and O.B. Banjoko. Assessment of Ground water Quality in a Typical Rural Settlement in Southwest Nigeria. International Journal of Environmental Research and Public Health., 4(4), 2007, $307-318$

[34]. M.J. Pelczar, E.C.S. Chan and R.K. Noel. Microbiology. (5th Edition, Tata Mc Graw Hill, New delhi. 2005) 571-572

[35]. P.O. Erah,, C.N. Akujieze and G.E. Oteze. The Quality of Groundwater in Benin City: A baseline study on inorganic chemicals and microbial contaminants of health importance inboreholes and open wells. Tropical Journal of Pharmaceutical Research, 1(2), 2002, 75-82.

[36]. A.A. Rogbesan, K.I.T. Eniola and A.B. Olayemi. Bacteriological Examination of some Boreholes within University of Ijebu-Ode. Nigerian Journal of Pure and Applied Science, 5(3), 2002, 117 - 223. 